\title{
Open versus arthroscopic ankle arthrodesis: a systematic review and meta-analysis
}

\author{
Tsz Ngai Mok ${ }^{1,2 \dagger}$, Qiyu He ${ }^{1,2 \dagger}$, Soundarya Panneerselavam², Huajun Wang ${ }^{1}$, Huige Hou', Xiaofei Zheng ${ }^{1}$, \\ Jinghua $\operatorname{Pan}^{3^{*}}$ and Jieruo $\mathrm{Li}^{1 *}$ (D)
}

\begin{abstract}
Background: Osteoarthritis $(\mathrm{OA})$ is a growing health concern that affects approximately 27 million people in the USA and is associated with a $\$ 185$ billion annual cost burden. Choosing between open surgery and arthroscopic arthrodesis for ankle arthritis is still controversial. This study compared arthroscopic arthrodesis and open surgery by performing a systematic review and meta-analysis.
\end{abstract}

Methods: For the systematic review, a literature search was conducted in 4 English databases (PubMed, Embase, Medline and the Cochrane Library) from inception to February 2020. Three prospective cohort studies and 7 retrospective cohort studies, enrolling a total of 507 patients with ankle arthritis, were included.

Results: For fusion rate, the pooled data showed a significantly higher rate of fusion during arthroscopic arthrodesis compared with open surgery (odds ratio $0.25,95 \% \mathrm{Cl} 0.11$ to $0.57, p=0.0010$ ). Regarding estimated blood loss, the pooled data showed significantly less blood loss during arthroscopic arthrodesis compared with open surgery (WMD 52.04, 95\% Cl 14.14 to 89.94, $p=0.007$ ). For tourniquet time, the pooled data showed a shorter tourniquet time during arthroscopic arthrodesis compared with open surgery (WMD 22.68, 95\% Cl 1.92 to 43.43, $p=0.03$ ). For length of hospital stay, the pooled data showed less hospitalisation time for patients undergoing arthroscopic arthrodesis compared with open surgery (WMD 1.62, 95\% Cl 0.97 to 2.26, $p<0.00001$ ). The pooled data showed better recovery for the patients who underwent arthroscopic arthrodesis compared with open surgery at 1 year (WMD 14.73, 95\% Cl 6.66 to 22.80, $p=0.0003$ ).

Conclusion: In conclusion, arthroscopic arthrodesis was associated with a higher fusion rate, smaller estimated blood loss, shorter tourniquet time, and shorter length of hospitalisation than open surgery.

Keywords: Arthrodesis, Ankle Joint, Arthroscopy, Open surgery

\section{Background}

Osteoarthritis (OA) is a growing health concern that affects approximately 27 million people in the USA and is associated with a $\$ 185$ billion annual cost burden [1]. Disabling or even debilitating functional impairment is

\footnotetext{
* Correspondence: huajanve@foxmail.com; ilorugaie@163.com

${ }^{\dagger}$ Tsz Ngai Mok and Qiyu He contributed equally to this work.

${ }^{3}$ Department of Gastrointestinal Surgery, First Affiliated Hospital of Jinan University, Guangzhou 510630, Guangdong, China

'Department of Sport Medicine, First Affiliated Hospital of Jinan University, Guangzhou 510630, Guangdong, China

Full list of author information is available at the end of the article
}

the main symptom of end-stage ankle arthritis [2]. It can drastically alter the quality of life of a patient. Arthrodesis is one of the last options for patients when conservative treatment fails $[3,4]$.

Arthrodesis, via open surgery, is the traditional option for treating ankle arthritis, chronic instability, and degenerative deformity [5]. Pain relief and functional improvement of a foot with ankle degeneration are reasons why ankle arthrodesis might be highly recommended as a reliable treatment. However, arthrodesis alters biochemical performance and may cause foot pain, joint

C C The Author(s). 2020 Open Access This article is licensed under a Creative Commons Attribution 4.0 International License, which permits use, sharing, adaptation, distribution and reproduction in any medium or format, as long as you give appropriate credit to the original author(s) and the source, provide a link to the Creative Commons licence, and indicate if changes were made. The images or other third party material in this article are included in the article's Creative Commons licence, unless indicated otherwise in a credit line to the material. If material is not included in the article's Creative Commons licence and your intended use is not permitted by statutory regulation or exceeds the permitted use, you will need to obtain permission directly from the copyright holder. To view a copy of this licence, visit http://creativecommons.org/licenses/by/4.0/ The Creative Commons Public Domain Dedication waiver (http://creativecommons.org/publicdomain/zero/1.0/) applies to the data made available in this article, unless otherwise stated in a credit line to the data. 
arthritis, and bone fracture [6-8]. In the last decade, arthroscopic arthrodesis, which is an advanced technique for treating ankle problems, has been used. It has been an available option since 1983 [9]. It has been reported that arthroscopic arthrodesis is less invasive, and patients suffer less pain after surgery. However, the presence of poor skin and poor vascularity are relative contraindications [10]. The contraindications must be aware as they can lead to severe misalignments and bone loss [11].

Choosing between open surgery and arthroscopic arthrodesis for ankle arthritis is still controversial [12]. However, to our knowledge, only one systematic review and meta-analysis comparing the outcomes of open and arthroscopic methods of ankle fusion is available in the literature, but it did not contain data on postoperative improvement [3]. This study evaluated the fusion rate, effectiveness, complications and operative improvements by performing a systematic and meta-analysis that focused on all studies that met our criteria: studies that were comparing arthroscopic arthrodesis and open surgery for patients with ankle arthritis.

\section{Methods}

\section{Search strategy}

For the systematic review, a literature search was conducted using 4 English databases (PubMed, Embase, Medline and the Cochrane Library) from inception to February 2020. To maintain high sensitivity in our research, we decided to include relevant medical subject heading $(\mathrm{MeSH})$ terms, common keywords, and a comprehensive combination. No language restriction and no filters were set for the strategy. All the relevant published article bibliographies were reviewed. A total of 142 references were removed due to duplication, and 186 references were imported for initial screening of titles and abstracts (Fig. 1).

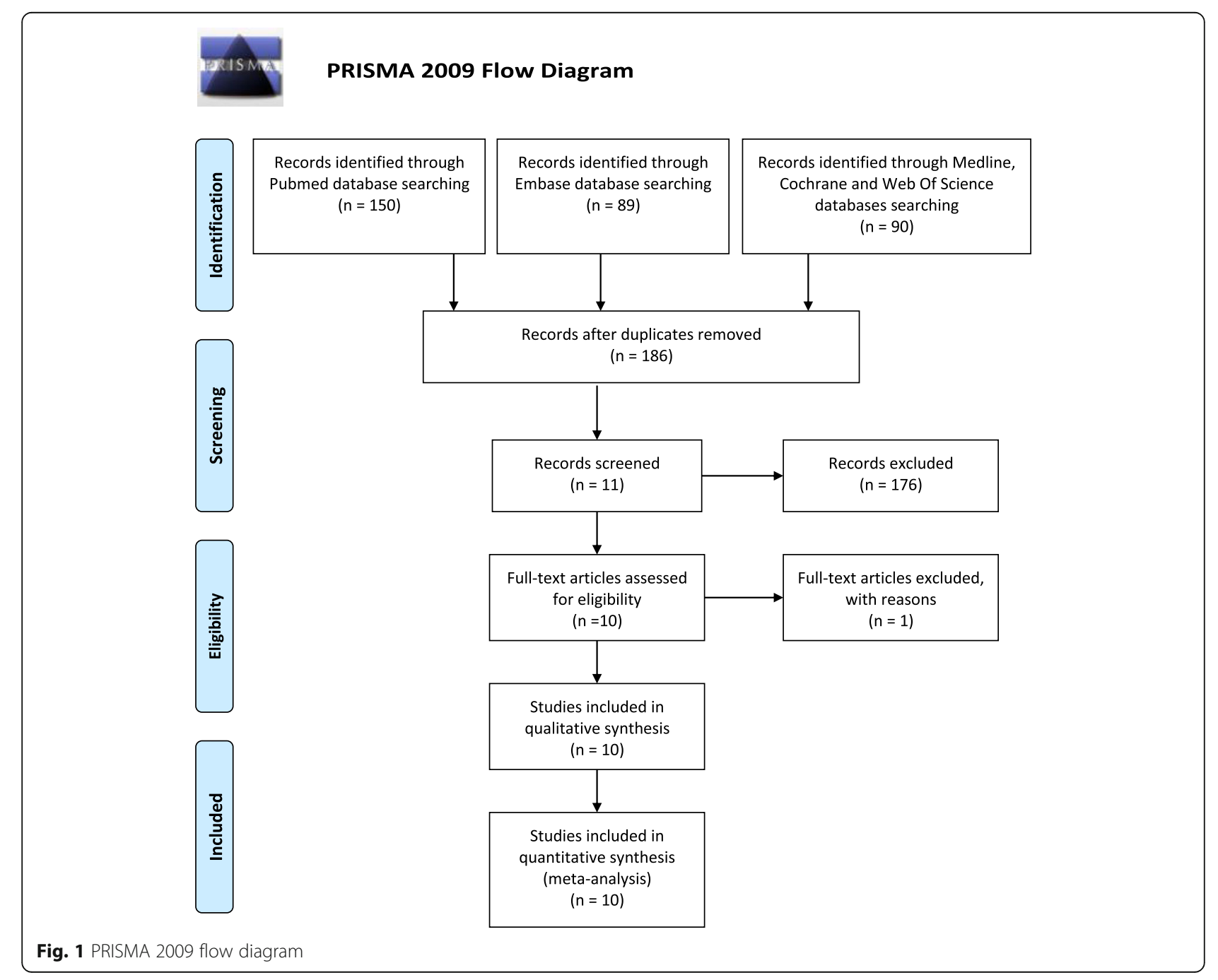




\section{Inclusion and exclusion criteria}

Two examiners screened all the references, including the titles and abstracts, separately so that the eligibility criteria could be achieved. Irrelevant articles and non-fulltext references were excluded. The inclusion criteria were as follows: (1) patients with arthritis, including post-traumatic arthritis, osteoarthritis, and end-stage arthritis, or patients with ankle instability; (2) comparative studies of open arthrodesis surgery and arthroscopic arthrodesis; and (3) one or more outcomes of interest shown in the studies. The excluded studies were (1) not original articles or (2) preclinical studies.

\section{Data extraction and quality assessment}

The following variables were extracted and doublechecked by the reviewers independently, and a quality assessment was performed. The Newcastle-Ottawa Scale (NOS) was used to assess the risk of bias of the observational studies. There is a maximum of nine stars in 3 domains ( 8 items): the selection of the study groups, the compatibility of the groups, and the ascertainment of the outcome of interest [13]. According to the scale, there are only low risk and high risk. Low risk was rated as one star, and high risk was rated as no star. Nine stars in a study indicated a low risk of bias, seven to eight stars in a review indicated a moderate risk of bias, and six or fewer stars in a study indicated a high risk of bias. Furthermore, a methodological index for nonrandomised studies (MINORS) was also used for the assessment. Twelve items were included in the checklist: clearly stated aim, inclusion of consecutive patients, prospective data collection, endpoints appropriate to study aim, follow-up period appropriate to study aim, less than $5 \%$ lost to follow-up, prospective calculation of study size, an adequate control group, contemporaneous groups, baseline equivalence of the groups and adequate statistical analyses. A score of $0-2$ is given for each item. The first 8 items are for those without a control group, and the maximum score is 16 . The last 4 items and the previous items are for those with a control group, and the maximum score is 24 . Zero indicated no record; 1 indicated an unclear recording; and 2 indicated that the outcome was fully reported in the article. Besides, the Coleman methodology score was added in order to indicate that a given study generally minimizes confounding factors and biases [14]. It is separated (Part A and Part B). The total score of the methodology is 100 . Two reviewers discussed whether there was any disagreement that needed to be resolved [15]. A third author was consulted when no agreement could be achieved. The baseline demographic and clinical characteristics of the study participants, including age, sex ratio, body mass index (BMI), sample size and lesion types, were recorded. At least 15 surgeons from different institutes participated in both the arthroscopic and open surgeries. The minimum duration of data collection was three years, and Peterson et al. [16] reported a maximum duration of 11 years (Table 1). Regarding the information about the interventions, the information collected about open and arthroscopic arthrodesis was included in the ratio in each study. In the investigation, we defined clinical fusion as a stable, painless ankle [16]. Adverse events and postoperative complications, the overall complication rate and the infection rates were recorded. Operation time, estimated blood loss, length of stay and Ankle Osteoarthritis Scale (AOS) score 12 and 24 months after surgery were extracted [26] to compare the effectiveness of open arthrodesis and arthroscopic arthrodesis. These were the only available assessments of functional improvement that could be pooled from the studies.

\section{Statistical analysis}

For dichotomous variables (i.e., fusion rate, infection rate and overall complication rate), the odds ratios (OR) and weighted mean differences (WMD) were calculated and reported with 95\% confidence intervals (CI) [27]. The algorithms proposed by Hozo et al. [18] were used when only the median, standard error or range was reported in the studies.

To assess statistical heterogeneity, a chi-square test with significance set at $p<0.10$ was used, including in the meta-analysis, and $\mathrm{I}^{2}$ statistics quantified heterogeneity. A fixed-effect model was applied for all variables with $\mathrm{I}^{2}<50 \%$. This means that there was no significant heterogeneity among the studies. All meta-analyses were directed by Review Manager Version 5.3 (RevMan, Copenhagen: The Nordic Cochrane Center, The Cochrane Collaboration, 2014). A two-tailed test of significance $(p<0.05)$ was used.

The publication bias was assessed by the Stat (version 11) with the funnel plot and the Egger test. In order to check the stability of pooled outcomes, a sensitivity analysis was conducted. Both Begg's test and Egger's test were used for assessing publication bias. The statistical significance within all comparisons was mathematically signified as $p<0.05$ [17].

\section{Results \\ Study characteristics}

Table 1 shows the characteristics of the 9 studies and their patients. Four of the 9 studies were conducted in the USA, 1 in Canada, 1 in China, 1 in Denmark and 1 in the UK. All the studies were published during the last 20 years, i.e., from 1990 to 2019. The studies included 3 prospective cohort studies and 7 retrospective cohort studies and enrolled a total of 507 patients with ankle arthritis. No randomised controlled trial was included. A total of 303 patients underwent arthroscopic arthrodesis, 
Table 1 Characteristics of the included studies

\begin{tabular}{|c|c|c|c|c|c|c|c|c|c|c|c|c|}
\hline Author & Year & Country & Journal & Lesion type & Procedure & $\begin{array}{l}\text { Follow- } \\
\text { up }\end{array}$ & $\begin{array}{l}\text { Sample } \\
\text { size }\end{array}$ & Arthroscopic & Open & $\begin{array}{l}\left(A^{a} \text { vs }\right. \\
\left.O^{b}\right)\end{array}$ & $\begin{array}{l}\left(\mathrm{A}^{\mathrm{a}} \mathrm{vs}\right. \\
\left.\mathrm{O}^{\mathrm{b}}\right)\end{array}$ & $\begin{array}{l}\left(A^{a} v s\right. \\
\left.O^{b}\right)\end{array}$ \\
\hline Meng [17] & 2013 & China & $\begin{array}{l}\text { Chinese Journal } \\
\text { of Reparative } \\
\text { and } \\
\text { Reconstructive } \\
\text { Surgery }\end{array}$ & Ankle arthritis & $\begin{array}{l}\text { Ankle } \\
\text { fusion }\end{array}$ & $\begin{array}{l}12 \\
\text { months }\end{array}$ & 30 & 14 & 16 & $\begin{array}{l}\text { Not } \\
\text { available }\end{array}$ & $\begin{array}{l}\text { Not } \\
\text { available }\end{array}$ & $\begin{array}{l}\text { Not } \\
\text { available }\end{array}$ \\
\hline $\begin{array}{l}\text { O'Brien T } \\
\text { S[18] }\end{array}$ & 1999 & USA & $\begin{array}{l}\text { Foot Ankle } \\
\text { International }\end{array}$ & $\begin{array}{l}\text { Post-traumatic } \\
\text { arthritis }\end{array}$ & $\begin{array}{l}\text { Ankle } \\
\text { fusion }\end{array}$ & NP & 36 & 19 & 17 & $\begin{array}{l}47.3 \text { vs } \\
44.6\end{array}$ & $\begin{array}{l}9 / 19 \text { vs } \\
7 / 17\end{array}$ & $\begin{array}{l}\text { Not } \\
\text { available }\end{array}$ \\
\hline $\begin{array}{l}\text { Nielsen KK } \\
\text { [19] }\end{array}$ & 2008 & Denmark & $\begin{array}{l}\text { Foot and Ankle } \\
\text { Surgery }\end{array}$ & $\begin{array}{l}\text { Post-traumatic } \\
\text { arthritis }\end{array}$ & $\begin{array}{l}\text { Ankle } \\
\text { fusion }\end{array}$ & $\begin{array}{l}12 \\
\text { months }\end{array}$ & 107 & 58 & 49 & $\begin{array}{l}\text { Not } \\
\text { available }\end{array}$ & $\begin{array}{l}\text { Not } \\
\text { available }\end{array}$ & $\begin{array}{l}\text { Not } \\
\text { available }\end{array}$ \\
\hline $\begin{array}{l}\text { Townshed } \\
\text { D [4] }\end{array}$ & 2013 & Canada & $\begin{array}{l}\text { Journal of Bone } \\
\text { and Joint } \\
\text { Surgery Am }\end{array}$ & $\begin{array}{l}\text { Post- } \\
\text { traumatic/ } \\
\text { primary OA }\end{array}$ & $\begin{array}{l}\text { Ankle } \\
\text { fusion }\end{array}$ & $\begin{array}{l}24 \\
\text { montsshs }\end{array}$ & 60 & 30 & 30 & $\begin{array}{l}59.4 \text { vs } \\
54.7\end{array}$ & $\begin{array}{l}11 / 30 \text { vs } \\
20 / 30\end{array}$ & $\begin{array}{l}27.4 \text { vs } \\
29.6\end{array}$ \\
\hline $\begin{array}{l}\text { Myerson } \\
{[20]}\end{array}$ & 1990 & USA & $\begin{array}{l}\text { Clinical } \\
\text { Orthopaedics } \\
\text { and Related } \\
\text { Research }\end{array}$ & $\begin{array}{l}\text { Post-traumatic } \\
\text { arthritis }\end{array}$ & $\begin{array}{l}\text { Ankle } \\
\text { fusion }\end{array}$ & $\begin{array}{l}23 \\
\text { months }\end{array}$ & 33 & 17 & 16 & $\begin{array}{l}\text { Not } \\
\text { available }\end{array}$ & $\begin{array}{l}7 / 17 \text { vs } \\
7 / 16\end{array}$ & $\begin{array}{l}\text { Not } \\
\text { available }\end{array}$ \\
\hline $\begin{array}{l}\text { Peterson } \\
{[21]}\end{array}$ & 2010 & USA & $\begin{array}{l}\text { Journal of foot } \\
\text { and Ankle } \\
\text { Surgery }\end{array}$ & Ankle arthritis & $\begin{array}{l}\text { Ankle } \\
\text { fusion }\end{array}$ & 6 months & 10 & 10 & 10 & $\begin{array}{l}56.2 \text { vs } \\
54.8\end{array}$ & $\begin{array}{l}5 / 10 \text { vs } \\
6 / 10\end{array}$ & $\begin{array}{l}37.36 \text { vs } \\
32.11\end{array}$ \\
\hline $\begin{array}{l}\text { Panikkar } \\
\text { [22] }\end{array}$ & 2003 & UK & $\begin{array}{l}\text { Foot and Ankle } \\
\text { Surgery }\end{array}$ & $\begin{array}{l}\text { Osteoarthritis/ } \\
\text { rheumatoid } \\
\text { arthritis/post- } \\
\text { traumatic }\end{array}$ & $\begin{array}{l}\text { Ankle } \\
\text { fusion }\end{array}$ & $\begin{array}{l}96 \\
\text { months }\end{array}$ & 41 & 21 & 22 & 65 vs 68 & $\begin{array}{l}17 / 3 \text { vs } \\
12 / 9\end{array}$ & \\
\hline $\begin{array}{l}\text { DeVrie } \\
s[23]\end{array}$ & 2019 & USA & $\begin{array}{l}\text { Journal of Foot } \\
\text { and Ankle } \\
\text { Surgery }\end{array}$ & $\begin{array}{l}\text { Ankle } \\
\text { instability }\end{array}$ & $\begin{array}{l}\text { Ankle } \\
\text { fusion }\end{array}$ & $\begin{array}{l}24.2 \\
\text { months }\end{array}$ & 55 & 43 & 12 & $\begin{array}{l}44.7 \text { vs } \\
39.5\end{array}$ & $\begin{array}{l}16 / 43 \text { vs } \\
6 / 12\end{array}$ & $\begin{array}{l}34.2 \text { vs } \\
33.1\end{array}$ \\
\hline $\begin{array}{l}\text { Quayle } \\
\text { [24] }\end{array}$ & 2016 & UK & $\begin{array}{l}\text { Foot and Ankle } \\
\text { Surgery }\end{array}$ & $\begin{array}{l}\text { Post-traumatic } \\
\text { arthritis }\end{array}$ & $\begin{array}{l}\text { Ankle } \\
\text { fusion }\end{array}$ & $\begin{array}{l}48 \\
\text { months }\end{array}$ & 79 & 50 & 29 & $\begin{array}{l}57 \text { vs } \\
61.9\end{array}$ & $\begin{array}{l}37 / 50 \text { vs } \\
19 / 29\end{array}$ & $\begin{array}{l}28.9 \text { vs } \\
28.0\end{array}$ \\
\hline $\begin{array}{l}\text { Schmid } \\
{[25]}\end{array}$ & 2017 & Canada & $\begin{array}{l}\text { Foot Ankle } \\
\text { International }\end{array}$ & $\begin{array}{l}\text { End-stage } \\
\text { ankle arthritis }\end{array}$ & $\begin{array}{l}\text { Ankle } \\
\text { fusion }\end{array}$ & $\begin{array}{l}54 \\
\text { months }\end{array}$ & 97 & 62 & 35 & $\begin{array}{l}57.4 \text { vs } \\
57.11\end{array}$ & $\begin{array}{l}39 / 62 \text { vs } \\
26 / 35\end{array}$ & $\begin{array}{l}28.2 v \\
28.8\end{array}$ \\
\hline
\end{tabular}

${ }^{\text {aArthroscopic arthordesis }}$

${ }^{\mathrm{b}}$ Open surgery

and 214 patients underwent open arthrodesis. In all cases, arthroscopy was used with standard anteromedial and anterolateral portals $[25,28]$.

Using the Newcastle-Ottawa scale, two analyses had a moderate risk of bias for study participation. One analysis had a high risk of bias. The graph in Fig. 2 demonstrates the summary and results of the methodological quality assessment. Regarding the MINORS, three articles had a score of 22 . Five analyses had scores between 18 and 20. One article had a score of 16. Supplemental Table S1 contains a summary of the results.

Overall, methodologic limitations were examined in the studies with an average Coleman methodologic score (mean: 61; SD: 10.42; range: 43-75). The reasons with the low score were a short period of follow-up, high percentage coverage of retrospective studies and unclear procedure for assessing outcomes (Supplemental Table S2).

\section{Primary outcome}

\section{Fusion rate}

Seven studies reported the fusion rate, and the pooled data showed a significantly higher rate of fusion during arthroscopic arthrodesis compared with open surgery (odds ratio $0.25,95 \% \mathrm{CI} 0.11$ to $0.57, p=0.0001$ ) in 128 of 167 patients. In addition, there was no significant heterogeneity between these two groups (for fusion rate assessing in arthroscopic arthrodesis with no three cannulated screws subgroup, 167 participants, odds ratio $0.26,95 \% \mathrm{Cl} 0.13$ to $0.55, p=0.0004$; arthroscopic arthrodesis with three cannulated screws subgroup, 200 participants, odds ratio $0.33,95 \% \mathrm{Cl} 0.12$ to $0.88, p=0.03$; Fig. 3a).

\section{Days to union}

Three studies assessed the days to union, and there was no difference between arthroscopic and open surgeries (WMD 1.62, 95\% CI -5.97 to 59.08, $p=0.11$ ). There 

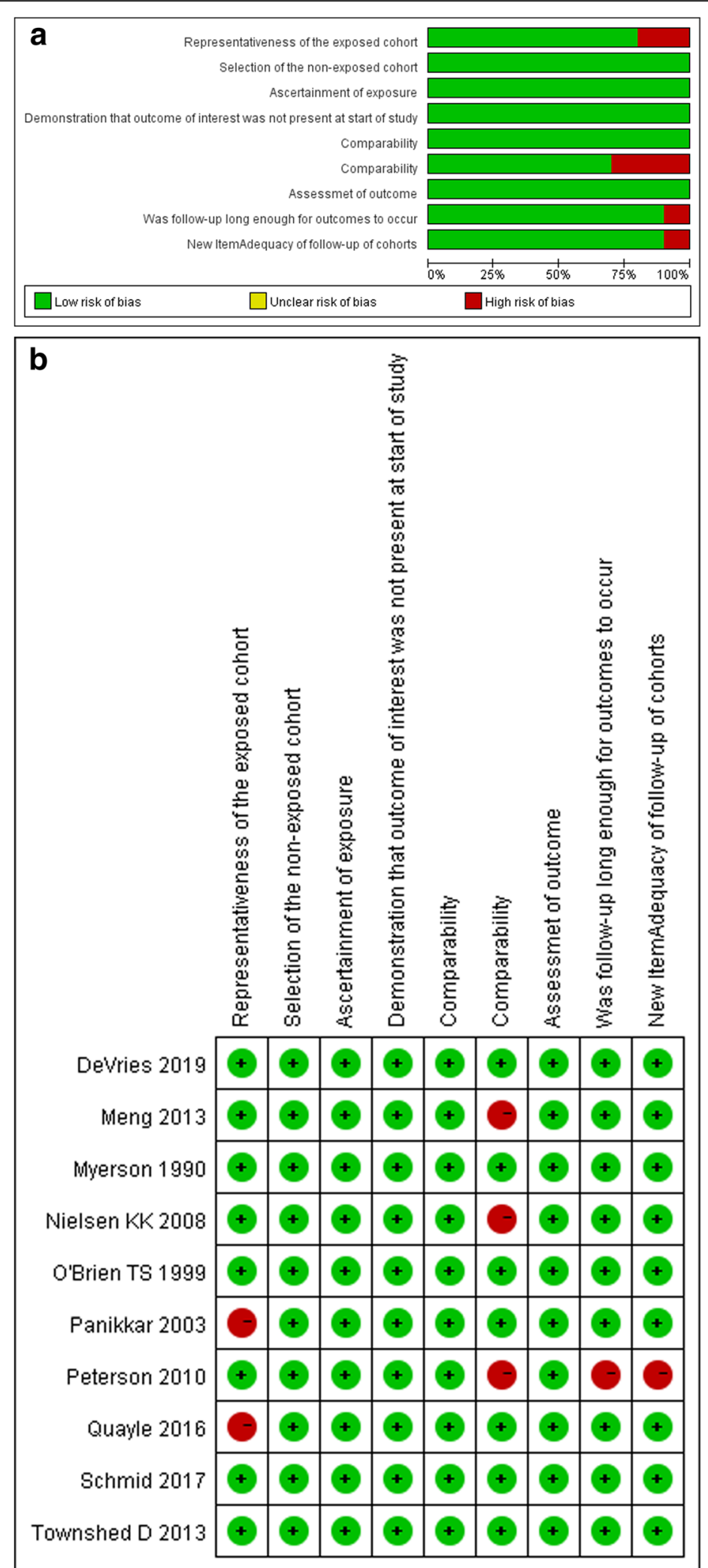

Fig. 2 Graph of summary and results of the methodological quality assessment 


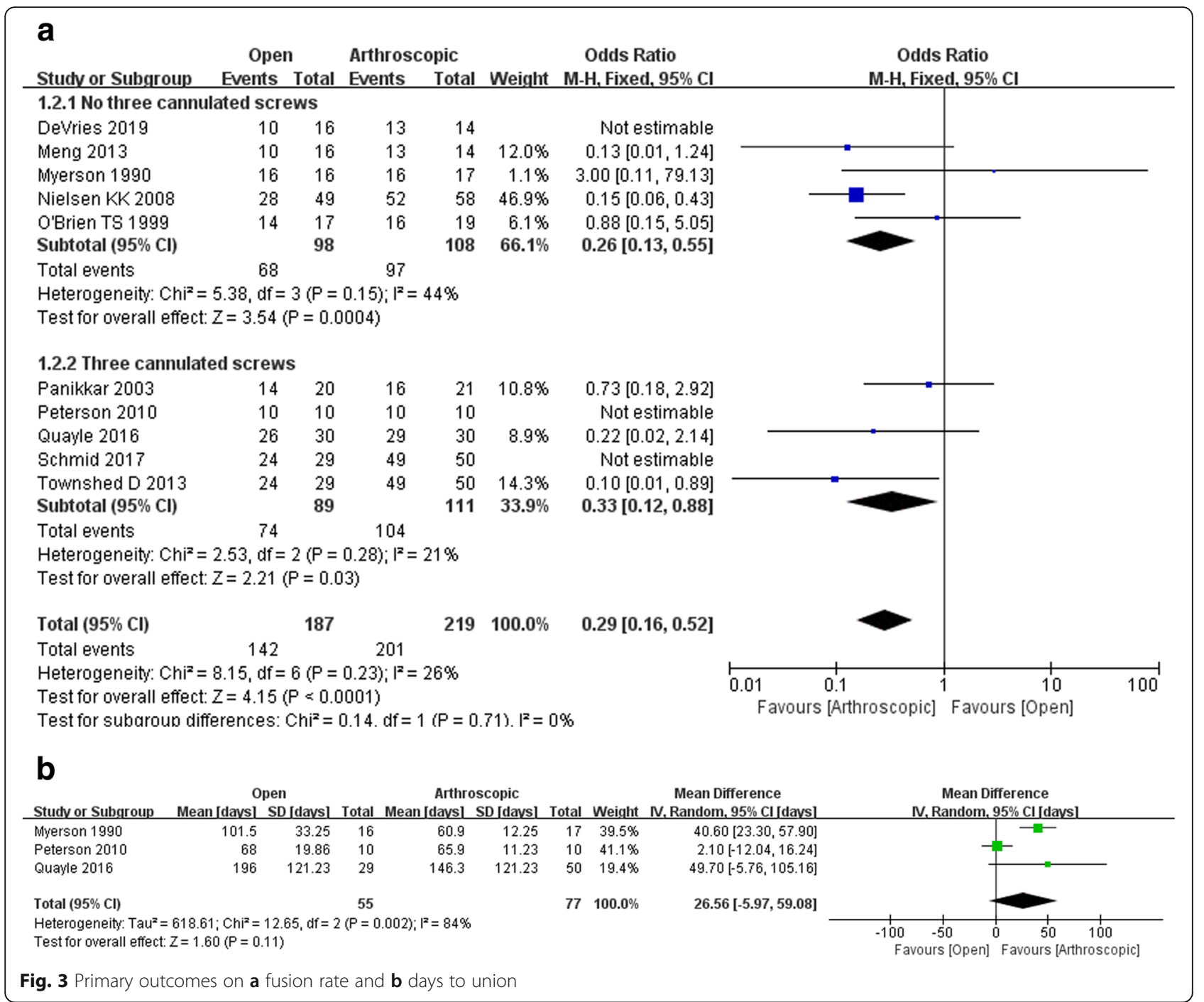

was no significant heterogeneity among these three studies (Fig. 3b).

\section{Surgical outcomes \\ Operation time}

Four studies reported the operation time. The level of heterogeneity was low (chi-square $=4.65, \mathrm{df}=3, \mathrm{I}^{2}=$ $35 \%, p=0.20$ ), and the pooled data from the four studies did not show a notable difference between arthroscopic arthrodesis and open surgery (WMD 3.72, 95\% CI 5.31, 12.76, $p=0.42$; Fig. 4a).

\section{Estimated blood loss}

Two studies assessed the estimated blood loss during surgery, and the pooled data showed significantly less blood loss during arthroscopic arthrodesis compared with open surgery (WMD 52.04, 95\% CI 14.14 to 89.94, $p=0.007)$. Also, there was no significant heterogeneity between the two groups (Fig. 4b).

\section{Tourniquet time}

Four studies reported the tourniquet time, and the pooled data showed remarkably shorter tourniquet times during arthroscopic arthrodesis compared with open surgery (WMD 22.68, 95\% CI 1.92 to $43.43, p=0.03$ ). There was significant heterogeneity among these four studies (Fig. 4c).

\section{Length of hospital stay}

Six studies reported the length of stay in the hospital, and the pooled data showed markedly less hospitalisation time for patients undergoing arthroscopic arthrodesis compared with open surgery (WMD 1.62, 95\% CI 0.97 to 2.26, $p<0.00001$ ), with a low level of heterogeneity (chisquare $=8.21, \mathrm{df}=4, \mathrm{I}^{2}=51 \%, p=0.08$ ) - for length of 


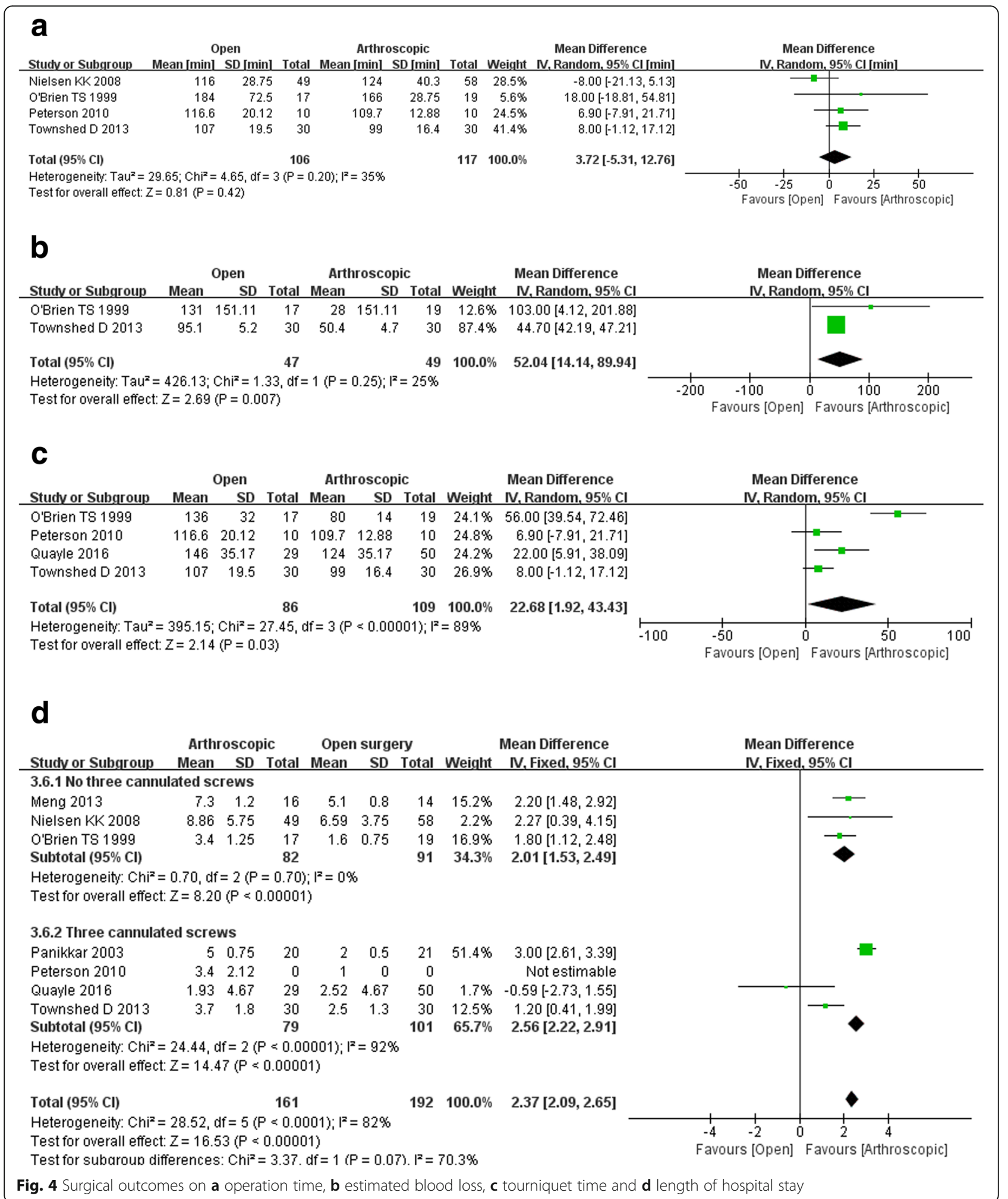

hospital stay assessing in arthroscopic arthrodesis with no three cannulated screws subgroup, 173 participants, odds ratio $2.01,95 \% \mathrm{Cl} 1.53$ to $2.49, p<0.00001$, while for that in arthroscopic arthrodesis with three cannulated screws subgroup, 180 participants, odds ratio $2.56,95 \% \mathrm{Cl} 2.22$ to 2.91, $p<0.00001$ (Fig. 4d). 


\section{Complications}

\section{Overall complication rate}

Eight studies assessed the overall complication rate, and there was no difference between arthroscopic arthrodesis and open surgery (WMD 1.70, 95\% CI 0.84 to 3.43, $p=$ $0.14)$. There was no obvious heterogeneity among these eight studies (for overall complication rate assessing in arthroscopic arthrodesis with no three cannulated screws subgroup, 231 participants, odds ratio 1.35, 95\% Cl 0.70 to 2.61, $p=0.37$; arthroscopic arthrodesis with three cannulated screws subgroup, 297 participants, odds ratio $1.81,95 \% \mathrm{Cl} 0.96$ to $3.42, p=0.07$; Fig. $5 \mathrm{a}$ ).

\section{Rate of infection}

Seven studies, including 365 patients, reported the rate of infection, and the pooled data showed no significant difference between patients who underwent arthroscopic arthrodesis and those who underwent open surgery (odds ratio $1.58,95 \%$ CI 0.60 to $4.16, p=0.36$ ). There was no significant heterogeneity among these seven studies (for overall complication rate assessing in arthroscopic arthrodesis with no three cannulated screws subgroup, 206 participants, odds ratio $2.82,95 \% \mathrm{Cl} 0.79$ to $10.12, p=0.11$; arthroscopic arthrodesis with three cannulated screws subgroup, 159 participants, odds ratio $0.72,95 \% \mathrm{Cl} 0.16$ to $3.15, p=0.66$; Fig. $5 b)$.

\section{Postoperative outcomes}

\section{One year post-surgery}

Two studies reported the 1-year postoperative recovery with the AOS score. The pooled data showed markedly better recovery for the patients who underwent arthroscopic arthrodesis compared with those who underwent open surgery (WMD 14.73, 95\% CI 6.66 to $22.80, p=$ 0.0003 ) with a low heterogeneity (chi-square $0.49, \mathrm{df}=1$, $p=0.48, \mathrm{I}^{2}=0 \%$; Fig. $6 \mathrm{a}$ ).

\section{Two years post-surgery}

Two studies assessed the 2-year postoperative recovery using the AOS scale and reported that patients who underwent arthroscopic arthrodesis had no notably greater recovery than those who underwent open surgery (WMD $8.13,95 \% \mathrm{CI}-3.40$ to $19.99, p=0.48$ ). In addition, there was no significant heterogeneity between these two groups $\left(\mathrm{I}^{2}=40 \%, p=0.20\right.$; Fig. $\left.6 \mathrm{~b}\right)$.

\section{Publication bias}

Visual inspection of the Begg funnel plots for the fusion rate, overall complication and infection rate revealed symmetry (Fig. 7). To ensure that there was not publication bias, Egger's test was also conducted (Supplemental Table S3). There was no statistically significant publication bias for any of the three results $(95 \% \mathrm{Cl}-$
$1.58-2.88, p=0.75 ; 95 \% \mathrm{Cl}-0.96-2.97, p=1.19 ; 95 \% \mathrm{Cl}$ $-2.55-2.78, p=0.92$, respectively).

\section{Discussion}

This study conducted a systematic review and metaanalysis of comparative studies published since 1990 to compare the fusion rate, operative effectiveness, safety and postoperative outcomes of arthroscopic arthrodesis and open surgery for ankle arthritis. Although there are similar studies comparing ankle arthrodesis and open surgery, this study included the most publications, reflecting the latest surgical results and focusing on the results of arthroscopic arthrodesis and open surgery for ankle arthritis. Considering limitations of a learning curve and insufficient evaluation, the study results might be meaningful.

\section{Strength of the systematic review}

This study evaluated the two procedures using 4 perspectives: primary outcomes (fusion rate and days to union), surgical outcomes (operation time, estimated blood loss, tourniquet time and hospitalization length), complication outcomes (overall complication rate and infectious rate), and postoperative outcomes (AOS score at 12 and 24 months), unlike the previous study. These items formed a complete evaluation, from primary outcome to postoperative recovery. First, it was noted that there was no significant difference in days to union, which is contrary to previous studies [3]. Patients who underwent arthroscopic arthrodesis did not have a shorter time to union than those who experienced open surgery.

\section{Inferences and implications}

Regarding the rate of fusion, the meta-analysis showed that there was a remarkable difference between arthroscopic arthrodesis and open surgery, and the data support the most recent meta-analysis by Honnenahalli et al. [3]. Patients who underwent arthroscopic arthrodesis had a higher fusion rate than those who underwent open surgery. In arthroscopic arthrodesis, the soft tissue envelope is disrupted to a minimum degree, which enables the major functions of soft tissues close to the surgical site. The bone healing cascade is activated rapidly, so the bone heals rapidly and function improves in the early stage due to the minimum degree of soft-tissue envelope disruption $[4,19]$. The limited exposure causes significantly decreased periosteal stripping [20]. These theories may elucidate the high fusion rate for arthroscopic arthrodesis.

Additionally, this study is the first to assess the estimated blood loss, and the pooled data significantly favoured arthroscopic arthrodesis compared with open surgery. The data were pooled by O'Brien et al. [21] and 


\begin{tabular}{|c|c|c|c|c|c|c|c|c|c|}
\hline $\begin{array}{l}\text { a } \\
\text { Studv or Subgroup }\end{array}$ & $\begin{array}{l}\text { Oper } \\
\text { Events }\end{array}$ & \multicolumn{3}{|c|}{ Arthroscopic } & Weight & $\begin{array}{l}\text { Odds Ratio } \\
\text { M-H. Fixed, } 95 \% \mathrm{Cl}\end{array}$ & \multicolumn{3}{|c|}{$\begin{array}{c}\text { Odds Ratio } \\
\text { M-H, Fixed, } 95 \% \mathrm{Cl}\end{array}$} \\
\hline \multicolumn{10}{|c|}{ 2.4.1 No three cannulated screw } \\
\hline Devries 2019 & 2 & 12 & 6 & 43 & $7.5 \%$ & $1.23[0.22,7.07]$ & & & \\
\hline Myerson 1990 & 3 & 16 & 2 & 17 & $5.4 \%$ & $1.73[0.25,12.01]$ & & & \\
\hline Nielsen KK 2008 & 12 & 49 & 16 & 58 & $38.2 \%$ & $0.85[0.36,2.03]$ & & & \\
\hline O'Brien TS 1999 & 5 & 17 & 0 & 19 & $1.1 \%$ & $17.16[0.87,338.14]$ & & & \\
\hline Subtotal $(95 \% \mathrm{Cl})$ & & 94 & & 137 & $52.3 \%$ & $1.35[0.70,2.61]$ & & & \\
\hline Total events & 22 & & 24 & & & & & & \\
\hline \multicolumn{10}{|c|}{$\begin{array}{l}\text { Heterogeneity: } \text { Chi }^{2}=3.95, d f=3(P=0.27) ; l^{2}=24 \% \\
\text { Test for overall effect: } Z=0.90(P=0.37)\end{array}$} \\
\hline \multicolumn{10}{|c|}{ 2.4.2 Three cannulated screws } \\
\hline Panikkar 2003 & 6 & 20 & 5 & 21 & $11.8 \%$ & $1.37[0.34,5.49]$ & & & \\
\hline Peterson 2010 & 4 & 10 & 1 & 10 & $2.1 \%$ & $6.00[0.53,67.65]$ & & & \\
\hline Quayle 2016 & 9 & 29 & 4 & 50 & $7.0 \%$ & $5.17[1.43,18.79]$ & & & \\
\hline Schmid 2017 & 5 & 35 & 11 & 62 & $23.5 \%$ & $0.77[0.24,2.44]$ & & & \\
\hline Townshed D 2013 & 1 & 30 & 1 & 30 & $3.3 \%$ & $1.00[0.06,16.76]$ & & & \\
\hline Subtotal (95\% Cl) & & 124 & & 173 & $47.7 \%$ & $1.81[0.96,3.42]$ & & & \\
\hline Total events & 25 & & 22 & & & & & & \\
\hline \multicolumn{10}{|c|}{$\begin{array}{l}\text { Heterogeneity: } \mathrm{Chi}^{2}=5.92, \mathrm{df}=4(\mathrm{P}=0.21) ; \mathrm{I}^{2}=32 \% \\
\text { Test for overall effect: } Z=1.82(\mathrm{P}=0.07)\end{array}$} \\
\hline \multicolumn{2}{|l|}{ Total $(95 \% \mathrm{Cl})$} & 218 & & 310 & $100.0 \%$ & $1.57[0.99,2.48]$ & & & \\
\hline \multicolumn{10}{|c|}{$\begin{array}{lll}\text { Total events } & 47 & 46\end{array}$} \\
\hline $\begin{array}{l}\text { Heterogeneity: } \mathrm{Chi}^{2}= \\
\text { Test for overall effect } \\
\text { Test for subaroun dif }\end{array}$ & $\begin{array}{l}10.52, \mathrm{df}= \\
\mathrm{Z}=1.93(\mathrm{P} \\
\text { rences: } \mathrm{C}\end{array}$ & $\begin{array}{l}8(\mathrm{P}= \\
=0.05 \\
\mathrm{hi}^{2}=0 .\end{array}$ & $\begin{array}{l}=0.23) ; 1^{2} \\
\text { 5) } \\
0.39 . d f=\end{array}$ & $\begin{array}{l}24 \% \\
(P=0.5\end{array}$ & 53). $\left.\right|^{2}=09$ & & 0.2 & $\begin{array}{cc}0.5 & 1 \\
\text { Favours [Open] }\end{array}$ & 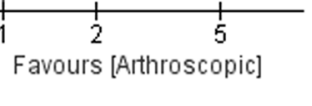 \\
\hline \multirow[b]{2}{*}{ Studv or Subgroup } & Open & & Arthros & opic & & Odds Ratio & \multirow{2}{*}{\multicolumn{3}{|c|}{$\begin{array}{c}\text { Odds Ratio } \\
\text { M-H, Fixed, 95\% } \mathrm{Cl}\end{array}$}} \\
\hline & Events & Total & Events & Total & Weight & M-H, Fixed, $95 \% \mathrm{Cl}$ & & & \\
\hline \multicolumn{10}{|c|}{ 2.1.1 No three cannulated screws } \\
\hline Meng 2013 & 1 & 16 & 0 & 14 & $6.6 \%$ & $2.81[0.11,74.56]$ & & & \\
\hline Myerson 1990 & 1 & 16 & 0 & 17 & $6.1 \%$ & $3.39[0.13,89.37]$ & & & \\
\hline Nielsen KK 2008 & 4 & 49 & 2 & 58 & $23.1 \%$ & $2.49[0.44,14.21]$ & & & \\
\hline O'Brien TS 1999 & 1 & 17 & 0 & 19 & $6.0 \%$ & $3.55[0.14,93.01]$ & & & \\
\hline Subtotal $(95 \% \mathrm{Cl})$ & & 98 & & 108 & $41.7 \%$ & $2.82[0.79,10.12]$ & & & \\
\hline Total events & 7 & & 2 & & & & & & \\
\hline \multirow{2}{*}{\multicolumn{10}{|c|}{$\begin{array}{l}\text { Heterogeneity: } \mathrm{Chi}^{2}=0.05, \mathrm{df}=3(P=1.00) ; \mathrm{l}^{2}=0 \% \\
\text { Test for overall effect: } Z=1.59(P=0.11)\end{array}$}} \\
\hline & & & & & & & & & \\
\hline \multicolumn{10}{|c|}{ 2.1.2 Three cannulated screw } \\
\hline Peterson 2010 & 1 & 10 & 1 & 10 & $12.3 \%$ & $1.00[0.05,18.57]$ & & & \\
\hline Quayle 2016 & 1 & 29 & 2 & 50 & $19.4 \%$ & $0.86[0.07,9.89]$ & & & \\
\hline Townshed D 2013 & 1 & 30 & 2 & 30 & $26.5 \%$ & $0.48[0.04,5.63]$ & & & \\
\hline Subtotal $(95 \% \mathrm{Cl})$ & & 69 & & 90 & $58.3 \%$ & $0.72[0.16,3.15]$ & & & \\
\hline Total events & 3 & & 5 & & & & & & \\
\hline \multicolumn{10}{|c|}{$\begin{array}{l}\text { Heterogeneity: } \mathrm{Chi}^{2}=0.17, \mathrm{df}=2(\mathrm{P}=0.92) ; \mathrm{I}^{2}=0 \% \\
\text { Test for overall effect: } Z=0.44(\mathrm{P}=0.66)\end{array}$} \\
\hline Total $(95 \% \mathrm{CI})$ & & 167 & & 198 & $100.0 \%$ & $1.59[0.64,3.99]$ & & & \\
\hline Total events & 10 & & 7 & & & & & & \\
\hline $\begin{array}{l}\text { Heterogeneity: } \mathrm{Chi}^{2}= \\
\text { Test for overall effect } \\
\text { Test for subaroun dif }\end{array}$ & $\begin{array}{l}2.05, \mathrm{df}= \\
Z=1.00(\mathrm{~F} \\
\text { erences: }\end{array}$ & $\begin{array}{l}6(P=0 \\
=0.32 \\
h i^{2}=1\end{array}$ & $\begin{array}{l}0.91) ; 1^{2}= \\
\text { 2) } \\
\text { 1.88. df }=\end{array}$ & $\begin{array}{l}0 \% \\
(P=0 .\end{array}$ & 17). $\left.\right|^{2}=4$ & & 0.01 & $\begin{array}{c}0.1 \\
\text { Favours [Open] }\end{array}$ & $\begin{array}{cc}10 & 100 \\
\text { Favours [Arthroscopic] }\end{array}$ \\
\hline Fig. 5 a Overall compli & ations and & b rate & e of infec & & & & & & \\
\hline
\end{tabular}

Townshed et al. [4]. Moreover, the tourniquet time during the operation was considerably shorter with arthroscopic arthrodesis than with open surgery. Although Meng et al. [23] mentioned that the operation time of the arthroscopic group was significantly longer than that of the open group, this study showed no significant differences in the operating time for the two procedures. There is only one relevant study mentioned in Meng et al. [23], but their pooled data were extracted from a larger sample size from different countries. Therefore, 


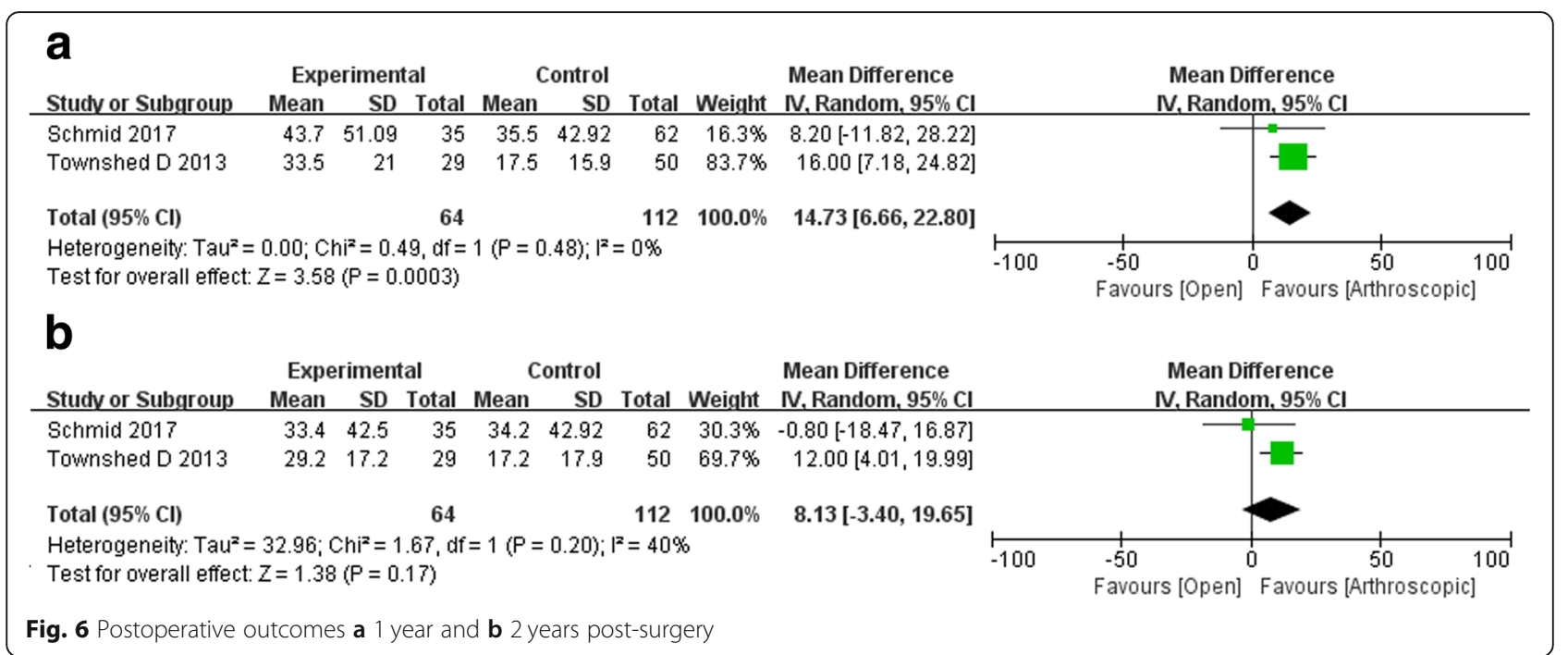

the risk of bias is minimised in the results. As a result, arthroscopic arthrodesis does not take longer to complete than open surgery.

Regarding complications, patients who undergo arthroscopic arthrodesis may require removal of a screw for prominence, superficial infections, deep vein thromboses/pulmonary emboli, fixation revision, stress fracture or deep infections after surgery [24]. The most common complications were non-union, delayed union and infection [28]. However, the study shows no significant difference between these two surgical procedures. It has been reported that patients require reoperation for similar complications in the two groups. This explains why there was no remarkable difference in either group given the similar postoperative radiological alignment [22]. The infection rates for the open surgery group and the arthroscopic group did not differ significantly. Some reports have shown results with infection rates in the open surgery group from 0 to $9 \%$ and very low infection rates in the arthroscopic technique group [29].

Moreover, postoperative improvements were studied via the AOS score. The arthroscopic arthrodesis group showed significantly better scores at 1 year compared with the open surgery groups. However, no significant difference between the groups at 2 years was noted. Since less area was damaged during arthroscopic arthrodesis than during open surgery, the tissues and functions recovered rapidly and in earlier stages, as per Townshend et al. [4]. Further study is needed to improve understanding of the clinical picture of the finding, especially with regards to education for patients choosing the best time to undergo reconstruction for their ankle arthritis [22]. This is a new finding compared with the previous study. Thus, patients who underwent arthroscopic arthrodesis recovered in a shorter time but showed similar bone reconstruction in the long term compared with those who underwent open surgery.

\section{Limitation of the systematic review}

There are several limitations despite these findings. First, the quality of the primary studies valued the final quality of the meta-analysis. Ten level VI studies were included. The inferences from this study may be limited. Second, a larger sample size is needed for some of the results,

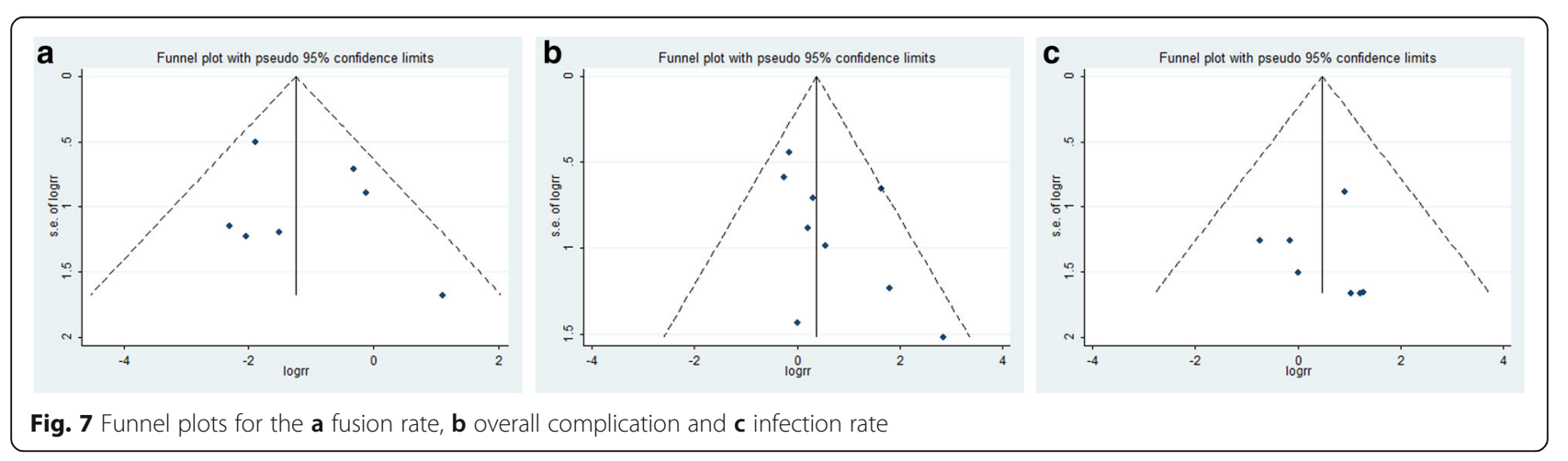


such as blood loss and functional improvement, which are drawn from few data points because they were not investigated in all the studies that were available for review. Most of our findings are similar with previous study that found very limited evidence of any benefit of open and arthroscopic fusion. Third, more longitudinal studies are needed since a 24-month follow-up cannot show the long-term effects or complications of the procedures [30].

Overall, we have assessed the comparison between arthroscopic arthrodesis and open surgery. To date, the fusion rate, tourniquet time and hospitalisation length have demonstrated the benefit of arthroscopic arthrodesis. According to Ling et al. [8], the effects of ankle arthrodesis on biomechanics or whether ankle arthrodesis leads to adjacent-joint arthritis are still uncertain without any common consensus. More benefit claims should be proved by data from well-designed trials in the future. Future researchers investigating any related treatment for end-stage arthritis should provide a common set of outcomes, and the outcome trials should be standardised.

\section{Conclusion}

Arthroscopic arthrodesis was associated with a higher fusion rate, shorter tourniquet time and shorter length of hospitalisation than open surgery. Nevertheless, we need to interpret the results with caution, pool RCT studies with larger sample sizes and perform comparative studies which will be required in prospective studies to evaluate the efficiency of arthroscopic arthrodesis.

\section{Supplementary information}

Supplementary information accompanies this paper at https://doi.org/10. 1186/s13018-020-01708-4

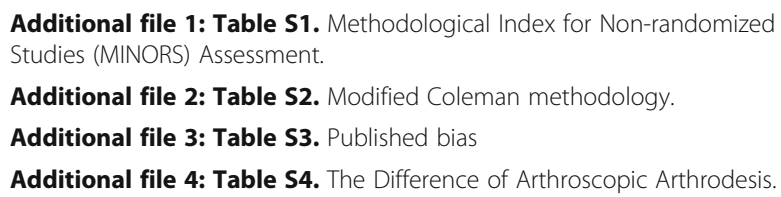

\section{Abbreviations}

AOS: Ankle Osteoarthritis Scale; BMI: Body mass index; Cl: Confidence intervals; MINORS: Methodological index for non-randomised studies; NOS: Newcastle-Ottawa Scale; OA: Osteoarthritis; OR: Odds ratios; SD: Standard deviation; WMD: Weighted mean differences

\section{Acknowledgements \\ Not applicable}

\section{Authors' contributions}

MTN and HQ designed the study and wrote the manuscript. PS and $\mathrm{HH}$ reviewed the risk of bias of the studies and the manuscript. $\mathrm{WH}$ and $\mathrm{ZX}$ extracted the data from the studies. PJ interpreted the results. $L J$ supervised the entire study. The authors read and approved the final manuscript.

\section{Funding}

No specific funding was provided for the study.

\section{Availability of data and materials}

The authors confirm that the data supporting the findings of this study are available within the article and its supplementary materials.

Ethics approval and consent to participate

Not applicable

\section{Competing interests}

The authors declare no competing interests.

\section{Author details}

${ }^{1}$ Department of Sport Medicine, First Affiliated Hospital of Jinan University, Guangzhou 510630, Guangdong, China. ${ }^{2}$ International School, Jinan University, Guangzhou 510632, Guangdong, China. ${ }^{3}$ Department of Gastrointestinal Surgery, First Affiliated Hospital of Jinan University, Guangzhou 510630, Guangdong, China.

Received: 9 March 2020 Accepted: 13 May 2020

Published online: 24 May 2020

\section{References}

1. Ewalefo SO, et al. Management of posttraumatic ankle arthritis: literature review. Current reviews in musculoskeletal medicine. 2018;11(4):546-57.

2. Glyn-Jones S, et al. Osteoarthritis. Lancet. 2015;386(9991):376-87.

3. Honnenahalli Chandrappa M, Hajibandeh S, Hajibandeh S. Ankle arthrodesis-open versus arthroscopic: a systematic review and meta-analysis. J Clin Orthopaedics Trauma. 2017:8(Suppl 2):S71-7.

4. Townshend D, et al. Arthroscopic versus open ankle arthrodesis: a multicenter comparative case series. J Bone Joint Surg Am. 2013;95(2):98102.

5. Mendicino SS, Kreplick AL, Walters IL. Open ankle arthrodesis. Clin Podiatr Med Surg. 2017;34(4):489-502.

6. Wang $Y$, et al. Effects of ankle arthrodesis on biomechanical performance of the entire foot. PLoS One. 2015;10(7):e0134340.

7. Kim HJ, et al. Total ankle arthroplasty versus ankle arthrodesis for the treatment of end-stage ankle arthritis: a meta-analysis of comparative studies. Int Orthop. 2017:41(1):101-9.

8. Ling J, et al. Investigating the relationship between ankle arthrodesis and adjacent-joint arthritis in the hindfoot: a systematic review. J Bone Joint Surg Am. 2015;97:513-9.

9. Piraino JA, Lee MS. Arthroscopic ankle arthrodesis: an update. Clin Podiatr Med Surg. 2017:34(4):503-14

10. Elmlund AO, Winson IG. Arthroscopic ankle arthrodesis. Foot Ankle Clin. 2015:20(1):71-80.

11. Wagner E, Melo R. Subtalar arthroscopic fusion. Foot Ankle Clin. 2018;23(3): 475-83.

12. Gharehdaghi M, Rahimi H, Mousavian A. Anterior ankle arthrodesis with molded plate: technique and outcomes. Arch Bone Jt Surg. 2014:2(3):203-9.

13. Lo CK-L, Mertz D, Loeb M. Newcastle-Ottawa scale: comparing reviewers' to authors' assessments. BMC Med Res Methodol. 2014;14:45.

14. Pinski JM, et al. Low level of evidence and methodologic quality of clinical outcome studies on cartilage repair of the ankle. Arthroscopy. 2016;32(1): 214-22.e1.

15. Sobieraj DM, et al. Association of inhaled corticosteroids and long-acting $\beta$ agonists as controller and quick relief therapy with exacerbations and symptom control in persistent asthma: a systematic review and metaanalysis. Jama. 2018;319(14):1485-96.

16. Peterson KS, Lee MS, Buddecke DE. Arthroscopic versus open ankle arthrodesis: a retrospective cost analysis. J Foot Ankle Surg. 2010;49(3):242-7.

17. Wang $Y$, et al. Auditing complex concepts of SNOMED using a refined hierarchical abstraction network. J Biomed Inform. 2012:45(1):1-14.

18. Wang $\mathrm{S}$, et al. Efficacy of totally laparoscopic compared with laparoscopicassisted total gastrectomy for gastric cancer: a meta-analysis. World J Clin Cases. 2020;8(5):900-11.

19. Szczęsny, G., Fracture Repair: Its Pathomechanism and Disturbances. Trauma Surgery, ed. O.K.a.H. Topacoglu. 2018 
20. Myerson, M.S. and G. Quill, Ankle arthrodesis. A comparison of an arthroscopic and an open method of treatment. Clinical orthopaedics and related research, 1991(268): p. 84-95.

21. O'Brien TS, et al. Open versus arthroscopic ankle arthrodesis: a comparative study. Foot Ankle Int. 1999;20(6):368-74.

22. Schmid T, et al. Effect of preoperative deformity on arthroscopic and open ankle fusion outcomes. Foot Ankle Int. 2017;38(12):1301-10.

23. Meng Q, et al. Effectiveness comparison between arthroscopic and open ankle arthrodeses. Zhongguo Xiu Fu Chong Jian Wai Ke Za Zhi. 2013;27(3) 288-91.

24. Ovaska M. Complications in ankle fracture surgery. Acta Orthopaedica. 2015; 86(sup358):1-35.

25. DeVries JG, Scharer BM, Romdenne TA. Ankle stabilization with arthroscopic versus open with suture tape augmentation techniques. J Foot Ankle Surg. 2019:58(1):57-61.

26. Croft $\mathrm{S}$, et al. Association of ankle arthritis score with need for revision surgery. Foot Ankle Int. 2017;38(9):939-43.

27. Nuzzo, R.L., Making continuous measurements into dichotomous variables Pm r, 2019. 11(10): p. 1132-1134.

28. Quayle J, et al. Arthroscopic versus open ankle arthrodesis. Foot and ankle surgery. 2018;24(2):137-42.

29. Nielsen KK, Linde F, Jensen NC. The outcome of arthroscopic and open surgery ankle arthrodesis: a comparative retrospective study on 107 patients. Foot and ankle surgery. 2008;14(3):153-7.

30. Panikkar KV. A comparison of open and arthroscopic ankle fusion. Foot and Ankle Surgery. 2003

\section{Publisher's Note}

Springer Nature remains neutral with regard to jurisdictional claims in published maps and institutional affiliations.

Ready to submit your research? Choose BMC and benefit from:

- fast, convenient online submission

- thorough peer review by experienced researchers in your field

- rapid publication on acceptance

- support for research data, including large and complex data types

- gold Open Access which fosters wider collaboration and increased citations

- maximum visibility for your research: over $100 \mathrm{M}$ website views per year

At BMC, research is always in progress.

Learn more biomedcentral.com/submissions 